\title{
Otoritenin Teolojik Meşruiyeti: Kutsal Bir Fenomen Olarak Otorite
}

Şinasi GÜNDÜZ•

Theological Justification of Authority:

Authority as a Sacred Phenomenon

Citation/@: Gündüz, Şinasi, (2017). Theological Justification of Authority: Authority as a Sacred Phenomenon, Milel ve Nihal, 14 (1), 8-23.

Abstract: The authority that has been accepted as a sacred phenomenon by many religious traditions is related to God who is the highest authority and therefore all powers that have the right of authority have to legitimize their authority by God. Some religious traditions question the legitimacy of authoritarian powers, and accept it as legitimate if it is appropriate to the rules and orders defined by God. Some traditions, on the other hand, accept the current authorities as legitimate and supply them a background of theological justification. The cult of king-God supplies a perspective in this direction. Also the doctrine of every authoritarian structure was founded by God, and consequently has a legitimacy supplies a theological justification to all authorities. This doctrine that is expressed particularly by Christianity is closely connected to the development of such social structures as secularism, liberalism and democracy.

• Prof. Dr., İstanbul Üniversitesi, İlahiyat Fakültesi, Dinler Tarihi Anabilim Dalı [sigunduz@gmail.com] 
Key Words: Authority, theological justification, cult of king-god, Christianity, Islam

Atıf/C: Gündüz, Şinasi, (2017). Otoritenin Teolojik Meşruiyeti: Kutsal Bir Fenomen Olarak Otorite, Milel ve Nihal, 14 (1), 8-23.

Öz: Birçok dinsel gelenek kutsal bir fenomen olarak kabul ettiği otoriteyi, en kutsal olan Tanrıyla ilişkilendirir. Tanrı en üst otoritedir ve otorite yetkisine sahip olan tüm güçler meşruiyetini tanrıdan almak durumundadır. Bazı dinsel gelenekler tanrıdan hareketle mevcut otoriter güçlerin meşruiyetini tartışır. Buna göre tanrının belirlemiş olduğu kurallara ve sınırlara riayet ediyorsa otorite meşru olarak kabul edilir. Bazı dinsel geleneklerde ise mevcut otoriter yapılar esas alınarak bunlara teolojik meşruiyet zemini oluşturulur. Kral-tanrı kültü bağlamında otoriter güçlerin değerlendirilmesi bu bağlamdadır. Bunun dışında en dikkat çekici perspektif ise tanrının dünyevi egemenlik alanını insana bıraktığı ve bu doğrultuda nasıl olursa olsun her otoriter yapının teolojik bir meşruiyete sahip olduğu yaklaşımıdır. Özellikle Hıristiyanlık tarafından dillendirilen bu yaklaşımın, bir şekilde günümüzdeki sekülerizm, liberalizm ve demokrasi gibi yapıların gelişimiyle yakın ilişkisi vardır.

Anahtar Kelimeler: Otorite, teolojik meşruiyet, kral-tanrı kültü, Hıristiyanlık, İslam

Karar verme, kontrol etme, emretme ve yaptırım uygulama hakkına haiz olmayı ifade eden otorite yetkisinin kime ya da kimlere has olması gerektiği ve böylesi bir yetkinin kutsalla ilişkisi dini geleneklerin önemle üzerinde durduğu bir husustur. Birçok inanç sisteminde egemenliğin ve otoritenin teolojik bir bağlam taşıdığına inanılır. Tanrı inancına yer veren (teist) dinlerde tanrı ya da tanrılar aşkın bir varlık olarak tüm sıfat ve özelliklerinde mutlak üstünlüğü ifade eder. Tanrı; yaratan, düzenleyen, karar veren, yöneten, cezalandıran ve dilediğinde affeden üstün varlıktır. Bu vasıflar tanrının üstünlüğünün ayrılmaz bir parçası olarak kabul edilmekle birlikte, tanrının bu vasıflarını nasıl ve hangi bağlamda kullandığı konusu dinden dine farklılık arz eder.

Tanrının üstün özelliklerinin, özellikle yöneticilik, egemenlik, sahip/malik olma, hesaba çekme ve yargılayıcılık gibi otorite kavra- 
mıyla ilişkili aşkın vasıflarının evrenle ve insanla ilişkili boyutu bağlamında dinleri müdahaleci olan dinler ve müdahaleci olmayan dinler şeklinde iki kategoriye ayırmak mümkündür. Müdahaleci olmayan tanrı inancına yer veren geleneklerde tanrının otoritesi ve bununla yakından irtibatlı olan egemenlik, yöneticilik, yargılayıc1lık gibi hususlar özelde kozmolojik ve metafizik düzlemde düşünülür. Buna göre tanrı, bu evreni ve insanı yaratmış, bir düzen oluşturmuş ve sonra aşkınlığından dolayı kendi köşesine çekilmiştir. Örneğin tanrının varlı̆̆ını kabul etmekle birlikte tanrının evrene müdahalesini kabul etmeyen deist geleneklerin vahiy, risâlet, kitap gibi hususlara ve dünya yaşantısını düzenlemeye yönelik dini kural ve kaidelere mesafeli durduğu bilinmektedir. ${ }^{1}$ Müdahaleci olmaya dinsel geleneklere göre sosyal ve bireysel yaşantının düzeni insanın kendi sorumluluğundadır; dünyevi yaşamın otoriter güçleri sosyal ve siyasal yaşama egemen olan kişi ve kurumlardır.

Cahiliye dönemi Arap inancı ve Şamanizm gibi bazı geleneklerde inanılan üstün varlığın bir şekilde müdahaleci olmayan bir ulûhiyet olarak tasavvur edildiği dikkati çekmektedir. Örneğin İslam öncesi Arap geleneğinde üstün bir varlık olarak inanılan Allah'ın yaratıcı, düzenleyici ve rızık verici olduğuna inanılmakla birlikte, ${ }^{2}$ Allah'ın yöneticiliğine, yargılayıcılığına ve cezalandırıcıl1ğına yönelik itirazlar yapıldığ görülmektedir. Cahiliye dönemi Araplarının Allah tasavvuru bir çeşit deus otiosus (durağan/boş tanr1 $)^{3}$ kavramına tekabül etmektedir; yani mutlak üstünlüğü ve aşkınlığından dolayı evrenden elini eteğini çekmiş adeta emekliye ayrılmış olan bir tanrı tasavvuru... Araplara göre Allah, yarattığ1 ve düzene koyduğunu evrenle ve insanla doğrudan ilgilenmeyecek kadar yüce ve aşkındır; dolayısıyla bunlarla ilgilenme işini ikincil tanrısal varlıklara, toplumsal yapıda güçlüler ve eşraf olarak öne çıkan kişilere ve gruplara bırakmıştır. Bu nedenle Araplar, kendilerini Allah'a yakınlaştırsınlar diye Lat, Menat ve Uzza gibi ikincil birtakım ulûhiyetlere tapındıklarını söylemektedirler. "Allah'ı gereği

\footnotetext{
${ }^{1}$ Bkn. Westmoreland, C., Deism: The Knowledge of God-Based Reason and Nature, Lulu Press 2015.

2 Bkn. Ankebût 61-63.

${ }^{3}$ Liade, M, L.E. Sullivan, "Deus Otiosus", Encyclopedia of Religion, (second edition), ed. L. Jones, Thomson Gale 2005, c. 4, s. 2309-2313.
} 
gibi takdir edememek" olarak değerlendirilen bu hastalıklı tanrı inancını Kur'an şiddetle eleştirmekte ${ }^{4}$ ve Allah'ın yalnızca yaratan, düzenleyen ve rızık veren değil yöneten, sahip olan, egemen olan, yargılayan, hesaba çeken ve benzeri bütün üstün özelliklere sahip olan üstün güç olduğunu vurgulamaktadır.

İslam, Yahudilik ve Zerdüştilik gibi müdahaleci ve yargılayıcı tanrı tasavvuruna yer veren monoteist dinlerde ise, -aralarında bazı farklılıklar olsa da- tanrı tüm üstün vasıflarıyla otorite yetkisini mutlak anlamda kullanan üstün güç olarak değerlendirilir. Tanrı otoritenin yegâne kaynağıdır, yalnızca metafizik bağlamda değil her anlamda otorite yetkisini mutlak şekilde elinde tutar. Yahudilikte tanrı mutlak egemen olandır, hükümranlığı elinde tutandır, kraldır, kudretlidir, yargılayandır, cezalandırandır. ${ }^{5}$ İslam'da ise Allah mülkün sahibidir, maliktir, her şeye hâkimdir, hükmün yegâne kaynağıdır. ${ }^{6} \mathrm{O}$, yerin göklerin ve her ikisi arasındaki her şeyin, âlemlerin rabbidir ve ilahıdır. ${ }^{7}$ Her şeyin yaratıcısı ve düzenleyicisidir. Aynı zamanda o, yarattığı varlıkları gözetleyen, koruyan kollayan, onları yalnızca kendisine kulluktan sorumlu tutan üstün güçtür. Yarattığı varlıkları hesaba çekecek, cezalandıracak ya da affedecek olandır. İzzet ve şerefin yegâne kaynağıdır.8 İnsanlar için din, yani takip edilecek bir yol, yöntem, nizam ve düzen koyandır. ${ }^{9}$ $\mathrm{Bu}$ vesileyle insanlara bireysel ve sosyal yaşantılarında riayet etmeleri gereken hudutlar/sınırlar koyandır. ${ }^{10}$ Doğruyu ve yanlışı, haramı ve helali, yasal olanı ve olmayanı belirleyen bu sinırlara riayet kurtuluşun ve hidayetin yegâne vasıtasıdır. Allah, kendisine iman

\footnotetext{
4 "Allah'ı gereği gibi takdir edemediler. Yeryüzü kıyamet gününde bütünüyle O'nun elindedir; gökler sağ eliyle dürülmüştür. $\mathrm{O}$, onların ortak koştuklarından münezzehtir, yücedir." (Zümer 67).

${ }_{5}^{5}$ Örneğin bkn. İşaya 1:24, 49:26, Tekvin 49:24, Çıkış 15:18, Mezmurlar 132: 2, 5. Yahudi kutsal kitabında tanrının kral ve kudretli olan şeklinde tanımlanmasıyla ilgili olarak bkn. Byrne, M, The Names of God in Judaism, Christianity, and Islam, Continuum Int. Publ. Comp. 2011, s. 38-41.

${ }^{6}$ Ali İmrân 26, Tâhâ 114, Mü'minûn 116, Haşr 23, En'am 18.

${ }^{7}$ Fatiha 2, Sa'd 66, Nebe' 37.

8 Nisâ 139, Fâtır 10.

${ }^{9}$ Mâide 3.

${ }^{10}$ Nisâ 13.
} 
eden üstünlüğünü, egemenliğini, otoritesini kabul eden mü'minlerin velisidir. ${ }^{11}$

Bütün bu özelikleri dikkate alındığında İslam'a göre Allah, s1nırsız otorite sahibidir ve otorite ve egemenliğin yegâne kaynağıdır. Otorite yetkisine yönelik tüm merciler referansını ondan, yani onun koymuş olduğu hükümlerden, kurallardan almak durumundadır. Allah'ın koymuş olduğu bir kural ve kaide karşısında herhangi bir varlığın bunlara riayet etmekten başka bir seçeneği yoktur.

"Allah ve Resûlü bir konuda hüküm verdikleri zaman, hiçbir mü'min erkek ve hiçbir mü'min kadın için kendi işleri konusunda tercih kullanma hakları yoktur. Kim Allah'a ve Resülüne karşı gelirse şüphesiz ki o apaçık bir şekilde sapmıştır." 12

Bu çerçevede Allah'in belirlediği kural ve kaidelere dayalı olmayan ya da referansını Allah'ın kitabından almayan hiçbir yönetim, güç ve yetki kullanımı meşru değildir. Böylesi bir yapılanmayı İslam "cahiliye", yani aymazlık olarak niteler; cahiliye referansını Allah'tan almayan, Allah'ın belirlemiş olduğu kural ve kaidelere dayanmayan, Allah'ın dişındaki güç odaklarını, kişileri, kurumları, düzenleri ve değerleri esas alan sosyal, siyasal ve kültürel yapılardir.
“Cahiliye hükmünü mü arıyorlar? Kesin olarak ina- nacak bir toplum için, kimin hükmü Allah'ınkinden daha güzeldir?"13

Dolayısıyla insanlar ya da kurumlar tarafından kullanılacak olan otorite yetkisi, otoritenin mutlak mercii olan Allah'ın koymuş olduğu sınırlara (hudûdullâha) riayetle meşru olacaktır. İzzet, şeref ve güce dayanma gibi hususlar, ancak Allah'ın öngörmüş olduğu ilkeler dikkate alınmak suretiyle meşru ve doğru olacaktır. Bu çerçevede referansını Allah'a, Allah'ın kitabına dayandırmayan ya da Allah'tan başka güçlerle ilişkilendirilen her yapı İslam'a göre gayrimeşrudur. Kur'an'da, Allah'tan başka, Allah'ın belirlediği çerçeve

\footnotetext{
11 Bakara 257, Ali İmrân 68.

12 Ahzâb 36.

13 Mâide 50.
} 
dışında güç ve otorite mercilerine başvuranlar bu tutumları nedeniyle uyarılır ve kınanır. “... onların yanında şeref ve izzet mi arıyorlar. Oysa bütünüyle izzet Allah'a aittir."14

Bütün bunlardan anlaşllan husus İslam'da mutlak otorite yetkisi sadece Allah'a aittir. Dünyevi yaşamda tebarüz eden otoriter yapıların ve güçlerin meşruiyeti ise Allah'ın kitabında belirlemiş olduğu çerçeveye riayet açısından değerlendirilir. Bu durumda İslam herhangi bir sosyal ve siyasal yapının meşruiyetinin Allah'ın koymuş olduğu sinırlar doğrultusunda tartışılması gerektiğini vurgular. Buna göre Allah'ın belirlemiş olduğu kurallara ve sınırlara riayet ediyorsa bir otorite meşrudur. Allah'ın koymuş olduğu sınırlar dışında gerçekleşen her otorite tebarüzü ise bir haddini aşmadır, yetki gaspidır.

Tanrı inancına yer veren dinlerde genel olarak otoritenin tanrı ile irtibatlandırıldığı, dinin teolojik yapısına göre tanrı ya da tanrıların en üst düzeyde otorite olarak kabul edildiği bilinmektedir. Bu doğrultuda birçok dini gelenekte otorite yetkisi dayandığı referansı ve yapısı itibarıyla kutsaldır. Kutsal bir fenomen olarak otorite her şeyden önce tanrının ya da tanrıların kutsallığıyla yakın ilişkilidir. Bütün kutsiyetin kaynağı ve kutsallar kutsalı olarak Tanrı'nın sahip olma, egemen olma, yönetme, karar verme, yargılama, cezalandırma ve benzeri bütün nitelikleri, isimleri ve sıfatları da kutsaldır. Dolayısıyla en üst düzeyde Tanrı tarafından temsil edilen bu fenomen (egemenlik ve otorite) dayandığı referans açısından kutsaldır. Otorite yetkisi yapısı itibarıyla da kutsal bir fenomendir; çünkü sıra dışıdır, olağanüstüdür, sıradan ya da profan olanın dişında etkileyici bir güce sahiptir. Bu özellikler, yani sıra dişılık ve kendisinde etkileyici bir güç taşıma vasıfları, dinin kutsal saydığı/gördüğü her şey, her varlık, nesne, obje ya da durum için geçerlidir. Bu özellikleri nedeniyle kutsal, profandan yani kutsal olmayandan kesin çizgilerle ayrışmaktadır. ${ }^{15}$

Başta metafizik varlıklar ve kutsal addedilen sosyal ve kültürel varlıklar ve değerler olmak üzere dinsel gelenekte yer alan birçok

\footnotetext{
14 Nisâ 139.

${ }^{15}$ Kutsalın özellikleri konusunda bkn. Eliade, M, The Sacred and the Profane: The Nature of Religion, Rewohlt Taschenbuch Verlag 1957.
} 
kavram ve değer, kutsalın bir parçası olarak karşımıza çıkar. Vurguladığımız gibi teist geleneklerde kutsalın en üst ifadesi tanrı ya da tanrılardır. Tanrı, kutsallar kutsalıdır. Tüm kutsallar meşruiyetini kutsalın en üst ve nihai ifadesi olan bu yüce (üstün) varlıktan alırlar. Yahudiliğe göre kutsal olan Tanrı'dır. Tanrı kendisini “Ben kutsalım" diye niteler; ${ }^{16} \mathrm{o}$, "kutsallıkta görkemli, heybetiyle övgüye değer, harikalar yaratandır."17 Tanrı'nın kutsallığı var olan her şeyden farklılığıyla, eşsizliğiyle, mükemmelliğiyle, aşkınlığıyla, egemenliğiyle, yüceliğiyle yakından ilişkilidir.

“Her şeye egemen rab kutsal, kutsal, kutsaldır. Yüceliği bütün dünyayı dolduruyor."18 "Kutsallıkta Rabbin benzeri yok; Evet, senin gibisi yok, ya Rab! Tanrımız gibi dayanak yok." 19

Hıristiyan geleneğinde de kutsallık en üst düzeyde Tanrı'ya aittir; Tanrı kutsaldır, Tanrı'nın ismi kutsaldır, ${ }^{20} \mathrm{O}$ "Kutsal Babadır". ${ }^{21}$ Tanrı mükemmel olan, her şeye gücü yeten, doğru ve adil olan, gücü ve kudreti açısından bütün varlıklarda hayret uyandıran ve kendisinden korkulması gerekendir:

“Her Şeye Gücü Yeten Rab Tanrı, Senin işlerin büyük ve şaşılası işlerdir. Ey ulusların kralı, Senin yolların doğru ve adildir. Ya Rab, senden kim korkmaz, Adını kim yüceltmez? Çünkü kutsal olan yalnız sensin. Bütün uluslar gelip sana tapınacaklar. Çünkü adil işlerin açıkça görüldü." 22

\footnotetext{
${ }^{16}$ Levililer 11: 44, 19: 2.

${ }^{17}$ Çıkış 15: 11.

18 Yeşaya 6: 3.

191 Samuel 2: 2.

20 “Göklerdeki Babamız, Adın kutsal kılınsın” Matta 6: 9; Luka 11: 2. Ayrıca bkn. Luka 1: 49.

${ }^{21}$ Yuhanna 17: 11,

22 Bkn. Vahiy 15: 3-4.
} 
Tanrının yüceliğinin ayrılmaz parçası, günahtan ve hatadan mutlak uzak olmasıdır; hiçbir şey onunla karşılaştırılamaz. ${ }^{23}$

İslam'da da Allah kutsaldır; el-kuddûs, yani "en kutsal" ve "bütün eksikliklerden münezzeh olan" Allah'ın güzel isimleri arasindadır. ${ }^{24}$

Yalnızca Yahudilikte, Hıristiyanlıkta ve İslam'da değil bütün dini geleneklerde tanrı bu özelliğiyle yani sahip olduğu üstün vasıflarla kutsalın en üst ifadesi olmakla karşımıza çıkar. Bu nedenle bütün kutsallar ve kutsallıklar referansını Tanrı'dan almak durumundadır. Tanrının kutsallığı, yaratma, yönetme, egemen olma, sahip olma, yargilama, cezalandirma ya da affetme gibi tanr1sal niteliklerin de kutsallığı anlamına gelmektedir. Birçok dini gelenekte Tanrı, kutsallığını gerek peygamberler, azizler, ermişler ya da krallar ve imparatorlar gerekse kutsal mekânlar, zamanlar ve araç gereçler aracılıyla ifşa eder. Dünyevi anlamda tanrısal kutsallığın ifşasını gerçekleştiren bu kişiler, nesneler ya da zamanlar ve mekânlar, bir şekilde Tanrı'nın kutsallığıyla ilişkiye geçmek suretiyle Tanrının kutsallığını ifşa ederler.

Başta çoktanrıcı pagan gelenekler olmak üzere bazı inanç sistemleri toplumsal yaşamda de facto bir durum olarak tebarüz eden yapısına, yani otoritenin fiili/görünür ifadesi olan krallık ya da imparatorluk ve benzeri sosyal ve siyasal yönetimlere teolojik anlamda bir açıklama getirmek suretiyle, yönetmek, yargılamak, karar vermek, cezalandırmak ve affetmek gibi vasıfları elinde tutan mercilerin otorite yetkisiyle ilişkisini izah etmeye çalışmışlardır. De facto otoriter yapılara teolojik bir meşruiyet zemini hazırlamışlardir.

Bununla ilgili olarak dikkat çekici iki perspektif karşımıza çıkmaktadır. Bunlardan ilki kral-tanrı kültüdür. Kral-tanrı kültünde sosyal yaşamda iktidarı elinde tutan otoriteyi temsil eden kralın, imparatorun ve benzeri yöneticilerin, sahip oldukları otoriter güçle tanrısal bir görev ifa ettikleri düşünülür. Eski Mısır ve Roma'dan

23 "Çünkü herkes günah işledi ve Tanrı’nın yüceliğinden yoksun kaldı." Romalılara 3: 23. "Tanrı kötülükle ayartılmadığı gibi kendisi de kimseyi ayartmaz." Yakub 1: 13.

${ }^{24}$ Haşr 23, Cuma 1. 
Eski Mezopotamya ve Şinto geleneklerine kadar birçok kültürel yapıda krallar, imparatorlar ve benzeri bu otoriter güçlerin tanrının ya da tanrıların yeryüzündeki enkarnasyonları (hulûl etmiş, bedenleşmiş halleri) olduklarına inanılır. Örneğin Eski Mısır geleneğinde tanrıça "Hathor' un oğlu" olarak adlandırılan firavunların tanrı Horus'un yeryüzünde hulul etmiş hali oldukları düşünülmüştür. ${ }^{25}$ Şinto geleneğinde de ilk Japon imparatoru olan Jimmu'nun güneş tanrıçası Amaterasu'nun soyundan geldiğine inanılmıştır. ${ }^{26}$ Benzer şekilde Eski Roma ve Babil'de de krallar ve imparatorlar bir şekilde tanrısal ya da yarı tanrısal varlıklar olarak görülmüştür. Bütün bunlarda dikkati çeken husus, toplumsal yapı üzerinde tesis edilmiş olan otorite ve egemenliğin kral-Tanrı düşüncesiyle teolojik açıdan meşrulaştırılmaya ve desteklenmeye çalışılmış olmasıdır. Topluma egemen olan güçler, saltanat ve otoritelerine, teolojik bir geri plan hazırlamak amacıyla krallığın ve imparatorluğun şu ya da bu şekilde tanrısal nitelik taşıdığı veya yöneticilerin otorite yetkisini tanrısal güçlerden aldıkları düşüncesini topluma empoze etmişlerdir. Böylelikle Eski Roma'da sezarlar "divis filius" olarak tanımlanmıştır. Roma'da imparatorlar divi filius (tanr1 Filius), divi augustus (tanr1 Augustus) gibi adlandırmalar yanında Kyrios (Rab) ve Soter (Kurtarıcı) olarak tanımlanmıştır. ${ }^{27}$ İmparatorların "Tanrı" olarak görülmeleri ve onlara tapınılmasıyla ilgili verilere erken dönem Hıristiyan yazarların eserlerinde de rastlanılmaktadır. ${ }^{28}$

Sosyal yaşamda otoritenin en üst temsilcisi olan krallara ve imparatorlara dair bu algılar, bu otoriteryan güçlerin sıradan insanlardan farklı olarak sahip oldukları nitelikler sebebiyledir. Zira bu niteliklerin, yani yönetme, sahip olma, karar verici olma, cezaland1rıcı veya affedici olma gibi özelliklerin daha önce de vurguladığımız

\footnotetext{
${ }_{25} \mathrm{Bkn}$. Hart, G., The Routledge Dictionary of Egyptian Gods and Goddesses, Routledge 2005, s. 62, 71.

${ }^{26}$ Josephson, J.A., The Invention of Religion in Japan, University of Chicago Press 2012, s. 134.

${ }^{27}$ Bkn. Galinsky, K., Augustan Culture, Princeton University Press 1996, s. 17, 378; Schoeps, H.J., Paul: The Theology of the Apostle in the Light of Jewish Religious History, tr. H. Knight, Philadelphia: The Westminster Press 1961, s.18.

28 Örneğin bkn. Tertullian, The Apology, xxxiii, http://www.newadvent.org/fathers/0301.htm (Copyright (c) 2000 by Kevin Knight).
} 
gibi sıradan bireylerin sahip olmadıkları sıra dışı nitelikler olduğu düşünülmüştür.

$\mathrm{Bu}$ noktada otoritenin teolojik meşruiyet zemini konusunda ikinci bir tasavvur karşımıza çıkmaktadır. Bu da kralların, imparatorların ve benzeri yöneticilerin sahip oldukları gücü tanrıdan aldıklarına, yani yönetimlerini tanrısal belirlemeye ve onaya dayalı meşru bir zemine dayandırdıklarına dair kanaattir. Kral-tanrı kültünden daha yaygın ve etkin olan bu kanaat, Eski Mezopotamya ve Misır'dan Eski Roma'ya kadar kadim toplulukların hemen hepsinde oldukça yaygındır. Örneğin Eski Babilliler Hammurabi'nin otoritesini ve yasa koyuculuğunu tanrıya dayandırmışlar, onun, meşhur kanun kodeksini (Hammurabi kanunlarını) tanrı Şamaş'tan aldığına inanmışlardır. ${ }^{29}$ Benzer şekilde Eski Roma'da da sezarların tanrısal iradenin ve kelamın yeryüzündeki temsilcileri oldukları düşünülmüş ve dolayısıyla sezara itaatin tanrıya itaatle eşdeğer olduğuna inanılmıştır. Eski Mısırlılar ise krallarının yani firavunların sahip oldukları gücün tanrısal bir meşruiyete haiz olduğunu, zira firavunların yaşayan birer ulûhiyet olduğunu kabul etmişlerdir. ${ }^{30}$

De facto otoriter yapılara teolojik bir meşruiyet kazandırma tasavvuru yalnızca bu kadim geleneklerle sınırlı değildir. Diğer bazı geleneklerde de otoriter gücün tanrının kudret ve iradesiyle tesis edildiği ve dolayısıyla otoriteye itaatin tanrısal düzene riayetin bir parçası olduğu tezi kabul görmüştür. Bu konuda en dikkat çekici dinsel gelenek Hıristiyanlıktır. Ancak Hıristiyanlığa geçmeden önce İslam geleneği içinde de böylesi bir tasavvurun zaman zaman dillendirildiğine dikkat çekmekte yarar vardır. Yukarıda da değindiğimiz gibi aslında İslam her türlü otorite ve egemenlik kullanımının Allah'ın koymuş olduğu sinırlar ve kurallar çerçevesinde söz konusu olacağını vurgular. Bu doğrultuda hem kendisini Allah'ın vekili ya da halefi olarak görüp egemenlik ve otorite yetkisini Allah

${ }^{29}$ Paul, S.M., Studies in the Book of Covenant in the Light of Cuneiform and Biblical Law, Leiden: Brill 1970, s. 6-7.

${ }^{30}$ Bu nedenledir ki Kur'an'da Hz. Musa ile tartışmasında zamanın firavunu kendisinin Mısırın yegâne ilahı/rabbi olduğunu iddia etmekte (26:38) ve Hz. Musa'nın tebliğ ettiği öğretiye iman eden büyücülere tehditler savurmaktadır. "Ben size izin vermeden iman ettiniz ha!" dedi. "Şüphesiz bu bir hiledir, siz bunu şehirde kurmuşsunuz, yerli halkı oradan çıkarmak istiyorsunuz, sonra anlayacaksınız!" 7: 123. Ayrıca bkn. Şuarâ 49. 
adına kullanmaya çalışan teokratik bir yapılanmaya, hem de Allah'ın öngördüğü ilkeleri ve sinırları dikkate almayan her yapıya karşı çıkar. Zira her tür karar mekanizmasında ve egemenlik tesisinde Allah'ın öngördüğü kural ve kaidelerini dikkate almayan ve başka birtakım referanslara dayanan bir zihniyet, bir perspektif, esas itibarıla Allah'ın ulûhiyetine ve rubûbiyetine karşı çıkmış, başka güçleri ve değerleri Allah'a ortak koşmuş demektir. Bu nedenledir ki Kur'an'da herhangi bir konuda Allah ve Resulü bir hüküm verdiklerinde inanan bireye buna teslim olup itaat etmekten başka bir yol olmadığının altı çizilmektedir. ${ }^{31}$ Bununla birlikte tarihsel süreçte İslam toplumları içinde bazı yöneticilerin kendilerini "yeryüzünde Allah'ın gölgesi" olarak tanımladıkları,, 32 bir çeşit teokratik yapılanma sergiledikleri ya da Allah'ın kitabında öngörülen perspektifin dışında birtakım referansları sosyal ve siyasal yaşamda ön plana çıardıkları da bilinen bir gerçektir. Örneğin bu perspektif çerçevesinde Kur'an'da "Allah'a itaat edin, Resul'e itaat edin ve sizden olan emir sahiplerine" 33 ifadesindeki "sizden olan" ifadesi adeta atlanarak, her tür otoriteye itaatin şart olduğu tarzında bir yaklaşım topluma egemen olmuştur. Benzer şekilde günümüzde de çeşitli çevrelerde zaman zaman gündeme getirilen Allah'ın hâkimiyetinin, egemenliğinin kozmolojik ve metafizik düzlemde olduğu sosyal alanda ise egemenlik kullanımının insana ve devlete bırakıldığı şeklindeki görüşler yanında, Allah'ın kitabında öngörülen kural ve kaidelerin zamanın ruhuna göre yeniden okunup anlaşılması gerektiği ve bu durumda tarihsel şartların değişimiyle bu kural ve kaidelerin de yeniden yorumlanması gerektiği şeklindeki perspektifler de bilinmektedir. ${ }^{34} \mathrm{Bu}$ ve benzeri yaklaşımlarda esas itibarıyla zamanın egemen paradigmalarını, teokratik temayül, rasyonalizm, sekülerizm, liberalizm ve benzeri perspektiflerin etkili olduğu, İslam'ın ve İslami kaynakların bunlardan hareketle anlaşılıp yorumlanmaya çalışıldığı gözden kaçmamaktadır.

\footnotetext{
31 Ahzab 36.

${ }^{32}$ Aydın, M.A., “Anayasa”, Türkiye Diyanet Vakfi İslam Ansiklopedisi, İstanbul, c. 3, s. 160-161.

33 Nisâ 59.

${ }^{34}$ Örneğin tarihselci yorum konusunda bkn. Kotan, Ş., Kur'an ve Tarihselcilik, İstanbul: Beyan 2001.
} 
Otoriteye itaatin tanrısal düzenle yakından irtibatlı olduğuna kanaat açısından özellikle Hıristiyanlık dikkat çekicidir. Hıristiyanlıkta sosyal ve siyasal alanda egemenliği elde tutan otorite sahiplerinin, sahip oldukları bu gücü esas itibarıyla tanrıdan almış olduklarına dair bir perspektif ön plana çıkarılmaktadır. Hıristiyanlığa göre egemenlik/otorite esas itibarıyla tanrısal bir niteliktir. Dolayısıyla bu niteliği elinde bulunduran her kurum ya da kişi, elinde bulundurduğu bu tanrısal nitelik sayesinde yönetimini yasal bir zemine dayandırmaktadır. Hıristiyan teolojisinin şekillenmesinde kilit bir yere sahip olan Pavlus, insanları nerede yaşarlarsa yaşasınlar emri altında yaşadıkları otoriter yapıya itaate sevk etmektedir.

"Herkes, altında yaşadığı yönetime itaat etsin. Çünkü Tanrı'dan kaynaklanmayan yönetim yoktur. Var olanlar Tanrı tarafından tesis edilmiştir. Bu nedenle, yönetime karşı direnen, Tanrı buyruğuna karşı gelmiş olur. Karşı gelenler ise yargılanır." 35

Buna göre her yönetim meşrudur; çünkü yönetim işi tanrı tarafından tesis edilen ve tanrının gücüne dayanan bir olgudur.

Bu durumda egemen güçlere karşı çıkmak veya onlara itaat etmemek tanrısal bir nitelik olan otoriteye karşı gelmektir. Bu ise Tanrıya karşı gelmekle eşdeğerdir. Pavlus'a göre otoriteye itaatsizlik durumunda egemen güçlerin kullandığı kılıç, Tanrının gazabıdır, hizmetkârıdır: "Yönetim kılıcı boş yere taşımıyor; kötülük yapanın üzerine Tanrının gazabını salacak olan öç alıcı olarak Tanrının hizmetindedir". ${ }^{36}$ Dünyevi otoriteye ya da egemen güçlere isyan eden ve bu nedenle cezalandırılan kimseler, tanrısal düzene karşı çıtıklarından dolayı Tanrının gazabına uğramış olanlardır.

Sahip olunan gücün tanrı tarafından tesis edildiği kanaatiyle dünyevi otoriteleri meşrulaştıran Hıristiyanlık, bu yaklaşımıyla aynı zamanda egemenlik ve otorite açısından tanrısal âlem ve dünyevi âleme yönelik bir ayrım yapmaktadır. Tanrısal âlemdeki egemenlik karşısında dünyevi egemenliği elinde tutan güçlere bir

\footnotetext{
35 Romalilara 13:1-2.

36 Romalilara 13:4.
} 
açıklama getirmeye çalışmaktadır. Aslında bununla bir bakıma tanrının egemenliğini de sınırlama yoluna gitmektedir.

Yeni Ahit'te tanrısal egemenlik ve otorite "göklerin krallığı" ya da "göklerin egemenliği" kavramlarıyla ifade edilir. ${ }^{37}$ Yeni Ahit'te metafizik düzlemde egemenlik ve otoritenin tanrı ile şeytan arasında taksim edildiği dikkati çeker. Buna göre tanrı ilahi âlemin egemeni olarak görülürken şeytan ise yeryüzünün egemeni olarak karşımıza çıkar. Yeni Ahit'te bu dünyanın tanrısının Şeytan olduğu vurgulanır. 38 Ayrıca "yöneticiler", "güçler", "egemenler", "melekler" ve benzeri isimler verilen şeytani güçlerin bu dünyaya hükümran oldukları ifade edilir. ${ }^{39}$ Dolayısıyla, günah nedeniyle cennetten uzaklaşan insanın yaşamak durumunda olduğu yeryüzü şeytanın egemenlik alanıdır. Şeytanın otoritesi altındaki bu evrende insan günah ve ölümün tutsağıdır. İnsanın tanrının egemenliğine katılışı ve bu vesileyle kurtuluşu amacıyla yeryüzünde bedenleşen ilahi oğul İsa Mesih, insanların aklanması için çarmıhta acı çekip can vermek/ölmek suretiyle kendisini kefaret olarak sunmuştur. Hiristiyan teolojisindeki bir yoruma göre bu kefaret yeryüzünün egemeni olan şeytana sunulan bir kefarettir. ${ }^{40}$ Ancak Mesih'in ikinci kez yeryüzüne geleceği dönemde (Parousia) yeryüzünde şeytanın egemenliğine son verilecek ve egemenlik ve otorite tamamiyla bir tek mercide, tanrida toplanacaktır.

Bu öğreti çerçevesinde Tanrı'nın egemenliği ya da krallığı metafizik âleme yöneliktir. Yeryüzünün egemeni şeytan ve şeytani güçler olmakla birlikte, yeryüzündeki sosyal/siyasal alanda egemenliği krallar, imparatorlar ve benzeri yöneticiler üstlenirler. Bir diğer ifadeyle metafizik bağlamda şeytan tarafından üstlenilmiş

\footnotetext{
${ }^{37}$ Matta 3:2, Markus 1:14-15.

382 Korintliler 4:4.

${ }^{39}$ Bkn. 1 Korintliler 2:6, 8; Efesliler 2:2; Koleseliler 1:16.

${ }^{40}$ İsa Mesih, insanların ruhlarını tutsak etmiş ve onları günah ve ölüme bağımlı kılmış olan şeytana fidye olarak verilmiştir. Tanrı, şeytanın, ruhlar üzerindeki bu egemenliğine son vermek için İsa'yı ona teslim etmiş ve şeytan İsa'yı çarmıhta öldürmüştür. Her ne kadar böylelikle insan ruhları şeytanın tahakkümünden kurtarılmış olsa da bu, görünürde kötülük güçlerinin açık bir zaferidir. Ancak İsa'nın yeniden dirilmesiyle Tanrı şeytana karşı bir zafer elde etmiştir. Bkn. Weaver, J.D., "Violence in Christian Theology", http://www.crosscurrents.org/weaver0701.htm.
} 
olan dünyevi egemenliği sosyal ve siyasal anlamda krallar, imparatorlar ve diğer siyasal iktidarlar temsil ederler. Böylelikle Hiristiyanlıkta her ne kadar meşruiyetini Tanrıdan ve tanrısal nitelikten alıyor olsa da otorite ve egemenlik, bunu elde tutan güç ya da güçler açısından iki alanda ayrışmıştır. Dünyevi alanda siyasal iktidarlar metafizik alanda ise tanrı ve şeytan otorite ve egemenlik erkinin yürütücüsüdür. Hıristiyanlık bu ayrışmanın Parousia dönemine yani Mesih'in yeryüzüne ikinci gelişine kadar geçerli olduğunu zira Mesih'in ikinci kez yeryüzüne gelişiyle birlikte bütün iktidarların feshedilip otorite ve iktidarın yalnızca tanrıda toplanacağını düşünmektedir. ${ }^{41}$

Hıristiyanlık tarihine baktığımızda Roma ve İstanbul kiliseleri ve daha sonraki dönemlerde Katolisizm ve Protestanlık arasında otorite ve iktidar açısından yaşanan tartışmaların ve ayrışmaların arka planında yatan nedenler arasında tanrısal egemenlik ve dünyevi egemenlik alanlarına yönelik öğreti de önemli yer tutar. Şöyle ki İstanbul kilisesi, Yeni Ahit kaynaklı "herkes altında yaşadığı yönetime itaat etsin" ilkesi çerçevesinde, dünyevi otoriteyi ve egemenliği imparatorda toplayan Sezaropapist anlayışa bağlı kalırken, MS 5. yüzyılda Batı Roma'nın yıkılışından itibaren Roma kilisesi, oluşan otorite boşluğunu kendisi doldurmaya karar vermiş ve yalnızca bir kilise/cemaat yapılanması olarak değil aynı zamanda dünyevi anlamda egemen siyasal bir güç olarak da tarih sahnesine çıkmıştır. Nitekim Roma kilisesinin bütün egemenliği tek elde, kendisinde toplama temayülü, ilerleyen dönemde teokrasi ile sonuçlanmıştır. Bu durum Roma ile İstanbul arasındaki çekişmelerin ve ayrışmanın temel nedenlerinden birisi olarak tarihte yerini almıştır.

Roma kilisesinin yani Katolik geleneğin bu konumu Reform döneminde de şiddetle eleştirilmiş ve başta Luther olmak üzere reformistler tarafından Hıristiyan öğretisinden bir sapma olarak görülmüştür. Zira Hıristiyanlık, Mesih'in Krallığı döneminde tanrısal otoritenin tek başına yeryüzüne egemen olacağı döneme kadar, dünyevi egemenliğin imparator ve kralların elinde bulunduğunu ve onlara itaatin şart olduğunu belirtmiş, tanrısal egemenliğin ise kozmolojik ve metafizik boyutuna dikkat çekmiştir. Oysa teokrasi döneminde Roma kilisesi, bu yaklaşımın aksine egemenlik yetkisini

411 Korintliler 15:24-25. 
her alanda kendisinde toplamıştır. Reform dönemini izleyen süreçte, Batı dünyasında hızla büyüyen kilise karşıtı söylemlerin de etkisiyle, kilisenin kendisini gözden geçirmek durumunda kalması ve günümüzde yeniden asli konumuna dönerek dünyevi egemenliği laik iktidarlara bırakmasına kadar ${ }^{42}$ yüzyıllarca kilise iktidarı ve otoriteyi elinde bulunduran bir güç olarak tarihe geçmiştir.

Son söz olarak; insanın bireysel ve sosyal yaşantısında fiili anlamda tecrübe ettiği bir fenomen olan egemenlik ve otoriteye dinlerin genel anlamda kutsal bir alan olarak bakmakta oldukları görülmektedir. Mutlak egemenlik ve otorite yetkisini tanriya hasreden ve ancak tanrının öngörmüş olduğu sınırlara riayet bağlamında herhangi bir otoritenin meşru olacağını vurgulayan İslam gibi inanç sistemleri fiili anlamda otoriter gücü elde bulunduran yapıların dinin çerçevesini çizdiği meşruiyet alanı bağlamında gözden geçirilmesi gerektiğini öngörmüşlerdir. Buna karşılık çoğu dinsel gelenek ise otorite ve egemenliği de facto bir durum olarak kabullenmiş ve mevcut otoriter yapılara teolojik bir meşruiyet alanı üretme yoluna gitmişlerdir. Bu doğrultuda, bazı gelenekler otoriter güçlere doğrudan bir uluhiyet ya da teolojik bir mahiyet atfederken Hiristiyanlık gibi bazı gelenekler ise her tür otoritenin yapısı gereği meşru olduğu tarzında pragmatik bir perspektif geliştirmiştir. Bu perspektife göre, yapısı itibarıyla tanrısal bir nitelik olan otorite yetkisini elinde tutan güçler, kimlikleri ve yapıları ne olursa olsun tanrı tarafından seçilmiş güçlerdir; dolayısıyla bunlara ve bunların düzenine itaat tanrı tarafından tesis edilmiş düzene itaat, bunlara isyan ve başkaldırı ise tanrı düzenine başkaldırıdır.

\section{Kaynakça}

Aydın, M.A., "Anayasa”, Türkiye Diyanet Vakfi İslam Ansiklopedisi, İstanbul, c. 3.

Byrne, M, The Names of God in Judaism, Christianity, and Islam, Continuum Int. Publ. Comp. 2011.

Eliade, M, The Sacred and the Profane: The Nature of Religion, Rewohlt Taschenbuch Verlag 1957.

\footnotetext{
42 Kilisenin bu dönüşümünü E. Mortimer "Hıristiyanlığın asli doktrinine geri dönmek" olarak değerlendirir. Mortimer, E., Faith and Power: The Politics of Islam, London: Faber and Faber 1982, s.33.
} 
Eliade, M, L.E. Sullivan, "Deus Otiosus", Encyclopedia of Religion, (second edition), ed. L. Jones, c. 4, Thomson Gale, 2005.

Galinsky, K., Augustan Culture, Princeton University Press 1996.

Hart, G., The Routledge Dictionary of Egyptian Gods and Goddesses, Routledge 2005.

Josephson, J.A., The Invention of Religion in Japan, University of Chicago Press 2012.

Kotan, Ş., Kur'an ve Tarihselcilik, İstanbul: Beyan 2001..

Mortimer, E., Faith and Power: The Politics of Islam, London: Faber and Faber 1982.

Paul, S.M., Studies in the Book of Covenant in the Light of Cuneiform and Biblical Law, Leiden: Brill 1970.

Schoeps, H.J., Paul: The Theology of the Apostle in the Light of Jewish Religious History, tr. H. Knight, Philadelphia: The Westminster Press 1961.

Tertullian, The Apology, xxxiii, http://www.newadvent.org/fathers/0301.htm (Copyright (C) 2000 by Kevin Knight).

Westmoreland, C., Deism: The Knowledge of God-Based Reason and Nature, Lulu Press 2015.

Weaver, J.D., "Violence in Christian Theology", http://www.crosscurrents.org/weaver0701.htm. 